\title{
Criterii, tactici și metode de bază folosite în cercetarea la faţa locului
}

\section{Criteria, tactics and basic methods used in crime scene investigation}

\section{Gabriel Păduraru ${ }^{1}$}

Rezumat: În lucrarea de faţă dorim să aducem în atenţie câteva modalităţi și metode generale prin care efectuarea cercetării la faţa locului să contribuie la aflarea răspunsurilor cu privire la lămurirea împrejurărilor în care a avut loc un eveniment.

Cuvinte-cheie: cercetare la faţa locului, criminalistică, urme, probe.

Abstract: In this paper we want to present some general ways and methods by which conducting a crime scene investigation can bring an important contribution to finding out the answers regarding the clarification of the circumstances in which certain facts happened.

Keywords: crime scene investigation, forensics, traces, evidence.

\section{Introducere - urmele, martorul tăcut}

„Orice modificare a realităţii trebuie să se manifeste printr-o anumită schimbare în universul material”, afirma Edmond Locard (pionier al criminalisticii, care a trăit în prima jumătate a secolului al XX-lea). Criminalistica este o activitate dinamică, în evoluţie permanentă, legată strâns de evoluţia știinţei. Urme care nu puteau fi interpretate sau puteau fi interpretate insuficient la un moment dat, după un timp, prin metode noi de analiză, oferă indicii importante. Exemplul cel mai la îndemână este expertiza amprentei genetice, descoperită de Alec Jeffreys în 1985. Din acel moment, această expertiză a oferit soluţii clare și fără echivoc atât în cauze penale cât și în cauze civile. În acest context, numărul de urme exploatabile a crescut. Cercetarea la faţa locului are ca scop imortalizarea aspectelor de la locul faptei în cât mai multe unghiuri și ipostaze, relevarea și ridicarea urmelor.

Cercetarea la faţa locului este atributul echipelor de cercetare criminalistică întrunite la solicitarea organelor de cercetare penală (judecător în cazul cercetării judecătorești).

1 Expert criminalist în cadrul Institutului Național de Expertize Criminalistice București - Laboratorul Interjudețean Iași, email: gabipaduraru2004@yahoo.com . 
Interpretarea și analizarea urmelor face parte din atribuţiile expertului sau echipelor de experţi care, prin mijloace știinţifice, oferă detalii cu privire la modul de formare, cronologia formării urmelor precum și cu privire la obiectul sau fiinţa care a creat urmele respective.

Expertiza criminalistică are ca scop identificarea persoanelor și / sau a obiectelor creatoare de urme și totodată stabilirea împrejurărilor în care au fost create acele urme. Identificarea criminalistică are două mari caractere și anume stabilirea apartenenţei generice și stabilirea identităţii ${ }^{2}$.

Cercetarea la faţa locului trebuie să surprindă și să ofere cât mai multe aspecte și detalii pe baza cărora specialiștii să poată stabili obiectul sau fiinţa care a creat urma sau urmele precum și împrejurările în care acestea au fost create. Un tablou cât mai complet al locului unde a avut loc o infracţiune este esenţial în investigarea și aflarea adevărului. Amănunte sau aspecte care pot fi considerate la o primă vedere minore sau lipsite de importanţă pot oferi informaţii preţioase.

De exemplu, o persoană a fost lovită de o autoutilitară care se deplasa cu spatele în intenţia de a ieși dintr-un gang. Conducătorul auto a afirmat că persoana era aplecată și aranja cumpărăturile în sacoșă și în această poziţie nu putea fi observată de conducătorul auto. La faţa locului s-a constatat prezenţa unor fructe (prune) risipite pe carosabil dintr-o sacoşă pe care a avut-o victima asupra sa. Analizând aspectul și modul de aranjare a fructelor pe carosabil (Fig. 1), s-a putut afirma că acestea au fost proiectate de la o înălţime de cca $50 \mathrm{~cm}$ către înainte pe o direcţie perpendiculară la carosabil. Acest mod de proiectare relevă faptul că victima a avut o traiectorie specifică unei căderi în faţă datorită dezechilibrării moment în care persoana care cade întinde rapid mâinile în faţă în intenţia de a atinge solul, acest mod de reacţie este un gest reflex cunoscut şi denumit ca „reflexul parașutistului”. În acest mod a fost demontată suş̧inerea conducătorului auto. Acest amănunt coroborat cu leziunile constatate pe corpul victimei au clarificat dinamica producerii accidentului, impactul producându-se în timp ce persoana traversa aleea gangului din care ieșea autoutilitara.

${ }^{2}$ L. Ionescu, D. Sandu, Identificarea criminalistică, Editura Științifică, București,1990, p. 61. 


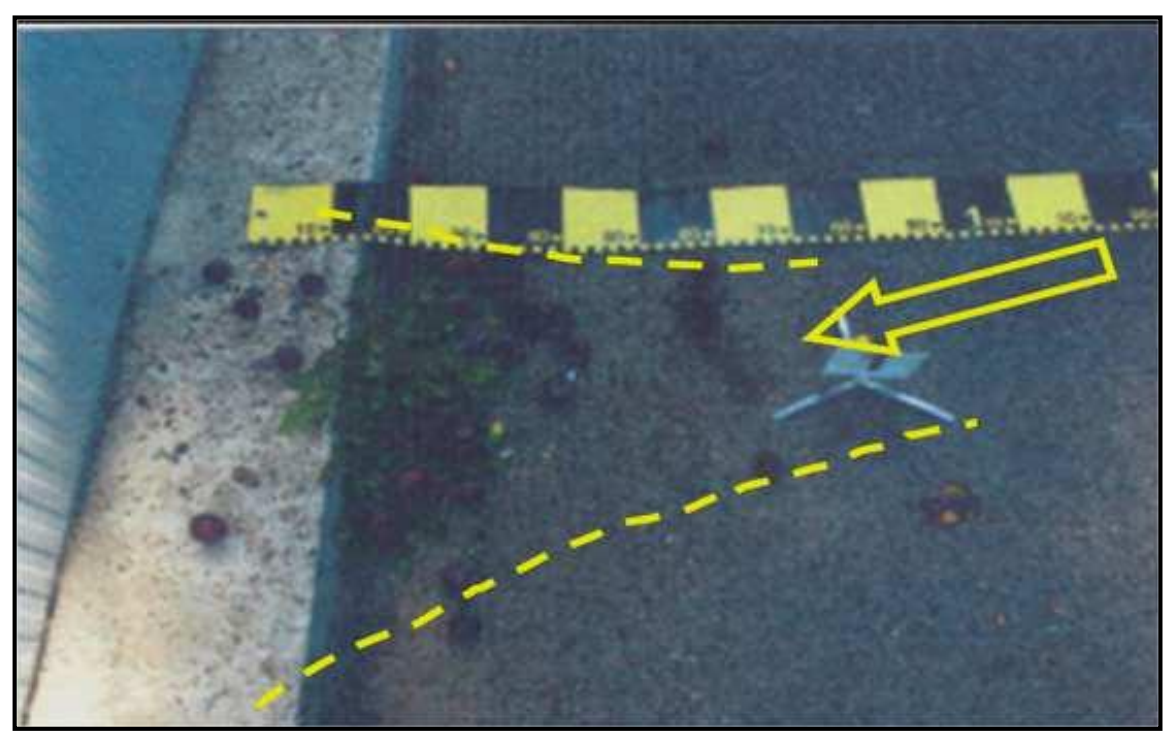

Fig. 1. Modul de răspândire a mijloacelor materiale de probă în cazul unui impact cu pieton în poziţie ortostatică aflat în traversare

În cazul unui omor, s-au efectuat fotografii și măsurători. Un amănunt care a fost trecut cu vederea a fost prezenţa larvelor de muscă pe suprafaţa cadavrului. Dimensiunile diferite ale acestora, deși nu fuseseră recoltate pentru examinare, au putut releva faptul că poziţia cadavrului fusese schimbată după un interval de cca 6 ore (Fig. 2 și 3).

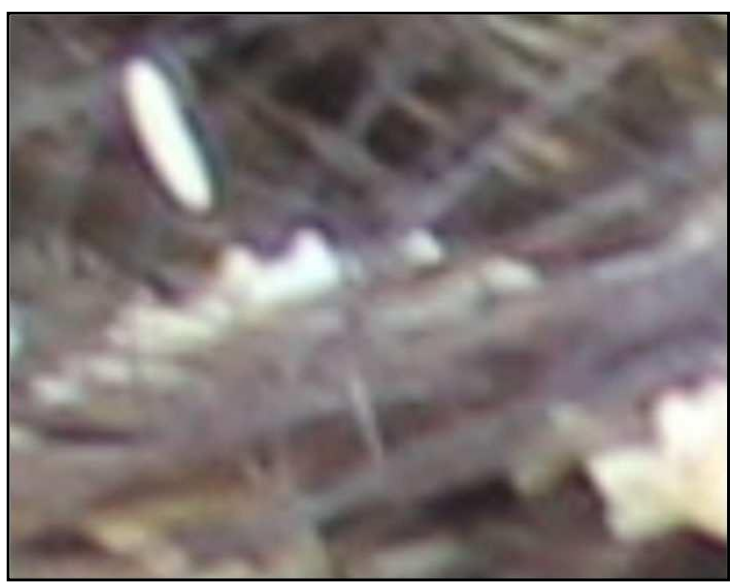

Fig. 2. Stadiul de dezvoltare al larvei depusă imediat după omor

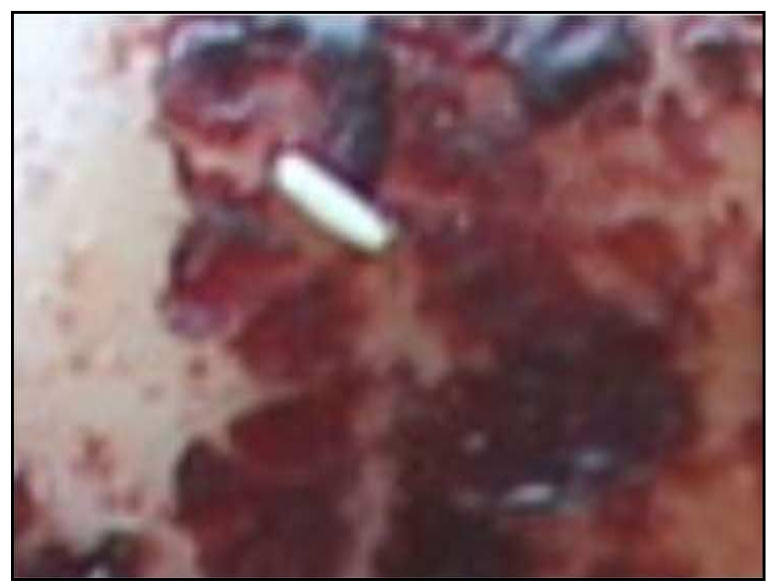

Fig. 3. Stadiul de dezvoltare al larvei depusă după mutarea cadavrului.

Împrejurările în care a avut loc un accident casnic, soldat cu moartea prin electrocutare a unui copil au putut fi lămurite datorită unei cercetări la faţa locului efectuată minuţios. Într-o locuinţă dintr-un sat a fost construită o dependinţă care în momentul producerii evenimentului nu era racordată la reţeaua electrică a casei. În dependinţa respectivă a fost improvizată o instalaţie electrică cu un cablu care trecea peste marginea acoperișului de tablă și se racorda direct la consola de alimentare a locuinţei. Un copil a luat în mână cablul respectiv pentru a-l muta. 
Copilul s-a electrocutat și a decedat pe loc. În seara în care a avut loc tragedia afară ploua torenţial, fapt confirmat în unanimitate de martori și staţia meteo. S-a presupus că a avut loc o fulgerare, fapt neconfirmat. La faţa locului s-a deplasat o echipă de la firma furnizoare de electricitate si nu a constatat niciun scurtcircuit sau porţiune din care să lipsească izolaţia cablului. Cauza electrocutării a fost stabilită în urma analizei tuturor fotografiilor efectuate, nu numai a acelora din planșa foto. Astfel, s-a constatat că pe consola de alimentare și acoperiș era plasată o creangă de la un arbore din curtea imobilului ( Fig. 4).

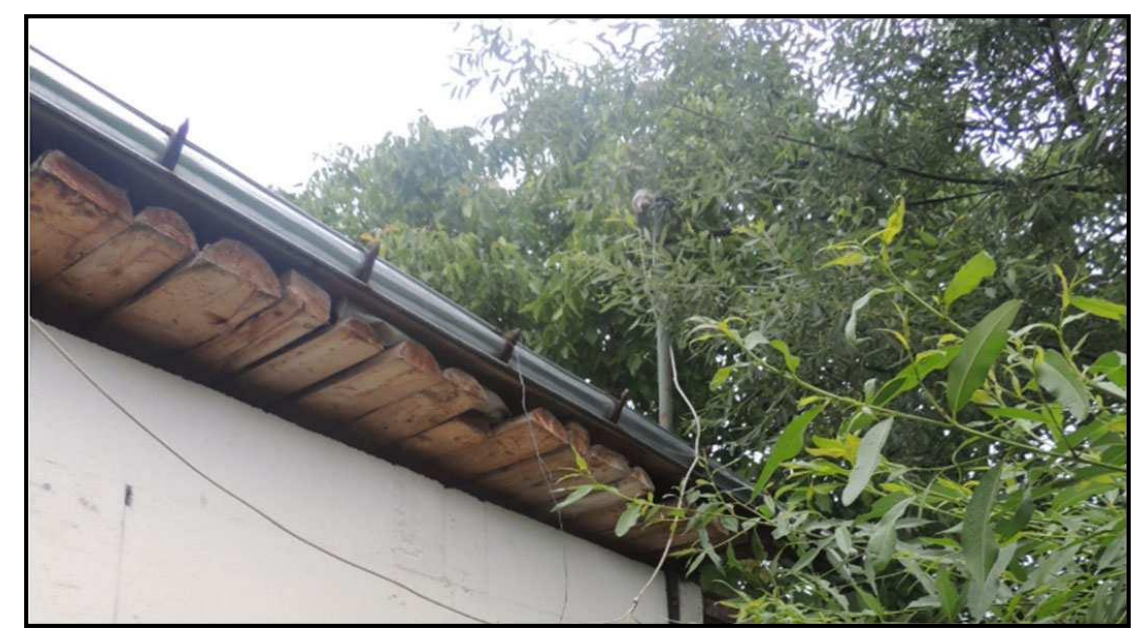

Fig. 4. Imaginea în care se observă cum vegetaţia creează o punte între consolă și acoperiș

Aparent nimeni nu a acordat atenţie acestei fotografii și nici situaţiei de fapt, însă, dacă ţinem cont că a plouat torenţial atunci ne putem da seama cu uşurinţă că vegetaţia prezentă fiind acoperită cu apă s-a constituit într-o punte de legătură între tabla acoperișului și consola de alimentare. Cablul, deși era izolat, era ud și, fiind în contact direct cu tabla acoperișului, a fost pus sub tensiune.

Am ales doar trei exemple în care se poate observa cum aspecte lipsite de importanţă la o primă vedere pot clarifica și pot oferi răspunsuri. Din acest motiv nu trebuie scăpat niciun aspect, chiar dacă pe moment pare irelevant.

Cercetarea la faţa locului poate fi urmată de una sau mai multe recercetări și, dacă este necesar, de una sau mai multe reconstituiri. Activităţile de cercetare la faţa locului trebuie să fie efectuate cu respectarea principiilor interpretării criminalistice ale urmelor la locul faptei ${ }^{3}$.

${ }^{3}$ Gh. Pășescu, Interpretarea criminalistică a urmelor la locul faptei, Editura Național, 2000 , p. 52 


\section{Principiile interpretării criminalistice ale urmelor la locul faptei}

\subsection{Principiul perceperii nemijlocite}

Acest principiu presupune ca specialistul care interpretează urmele să ia contact direct cu urmele la faţa locului. Când acest lucru nu este posibil, specialistul poate examina în mod direct și nemijlocit urmele prin intermediul fotografiilor, înregistrării video sau audio, mulaje etc.

\subsection{Principiul limitării surselor de informare}

Sursele de informare sunt limitate la locul faptei și la totalitatea urmelor descoperite. Desigur, specialistul poate apela la surse terţe de informare care constau în persoane sau grupuri de persoane cu un grad înalt de specializare în domenii ale științei. Declaraţiile administrate în cauză, indiferent că sunt date de persoana vătămată, autor sau martor, trebuie luate în considerare cu precauţie și doar sub beneficiu de inventar.

\subsection{Principiul corelaţiei urmelor}

Întotdeauna urmele descoperite la locul faptei sunt determinate de acţiuni succesive, sunt înlănţuite într-un traseu logic şi unic. Urmele sunt create de acţiunea unui făptuitor, a obiectelor folosite de acestea fie ca rezultat al obiectelor sau substanţelor folosite de făptuitor sau deja existente la locul faptei. Obiectele sau substanţele folosite sunt și ele purtătoare de urme, acestea nu rămân pasive, cu alte cuvinte se produce un transfer reciproc și corespondent ${ }^{4}$.

\subsection{Principiul cauzalităţii}

Conform acestui principiu, orice urmă a fost creată ca efect al unei acţiuni executate la locul faptei. Acţiunea poate fi creată de făptuitor, victimă, o terţă persoană care a avut contact cu locul fapte, insecte, animale, fenomene biologice, meteorologice etc.

Operaţiunea de interpretare a urmelor nu trebuie încheiată până când nu se găsește și nu se explică fenomenul sau cauza care a creat urma respectivă.

\subsection{Principiul identităţii}

Identitatea însumează caracteristicile și proprietăţile unui obiect, fenomen sau fiinţă și prin aceasta se deosebește de alt obiect, fenomen sau fiinţă.

Urmele își păstrează o perioadă de timp caracteristicile care le definesc, rămânând unice. Principiul identităţii în contextul interpretării presupune o distincţie clară între identitatea abstractă și identitatea concretă.

Identitatea abstractă există doar în planul gândirii și consideră că orice obiect sau fiinţă este identică doar cu ea însăși pe întreaga durată a existenţei. „Acest

${ }^{4}$ I. Mircea, Valoarea criminalistică a unor urme de la fața locului, Editura V. Goldiș, Arad, 1996, p. 28 
concept ideal neglijează practic deosebirile dintre obiecte făcându-le indiscernabile, or identitate fără deosebire nu există" 5 .

Identitatea concretă este considerată ca fiind „aceea care relevă unitatea dintre identitate și deosebire, la nivel existenţial, orice obiect fiind prin natura sa o sinteză de laturi contrare" .

Cercetarea criminalistică nu determină obiectul sau fiinţa în sine ci trebuie să ajungă la o identitate probantă. Aplicarea legii identităţii prin care se răspunde la întrebarea dacă urma a fost creată sau nu de acel obiect sau fiinţă corespunde scopului identificării criminalistice.

\subsection{Principiul realismului interpretării}

Interpretarea urmelor trebuie să furnizeze informaţii şi ipoteze realiste în contextul condiţiilor concrete de la locul faptei.

Observarea și analiza urmelor de la locul faptei trebuie efectuate metodic, cu orientarea către direcţia punerii în valoare a cât mai multor caracteristici ale urmelor, obiectelor sau fiinţelor creatoare de urme și a oricărei stări de fapt ce poate duce la formularea unei concluzii pertinente și realiste.

\subsection{Principiul demonstrării afirmaţiilor sau al credibilităţii}

Concluziile rezultate în urma analizei și interpretării criminalistice a urmelor în contextul locului faptei trebuie susţinute prin argumente solide care presupun calcule, experimente, simulări, măsurători, comparaţii etc. sau orice procedee ori metode tehnico - ştiinţifice convingătoare. „Demonstraţia reclamă să fie făcută în așa fel încât să permită organului judiciar să vadă ce a văzut specialistul sau expertul criminalist cu ajutorul aparaturii din dotare"

\subsection{Principiul elaborării ipotezelor după contactul cu locul faptei}

Interpretarea urmelor nu își propune și nici nu trebuie să confirme idei sau ipoteze emise de unii membri ai echipei de cercetare sau persoane terţe. Adesea apar, mai ales în presă, persoane care emit ipoteze sau scenarii pe baza unor imagini care surprind urme sau pe baza unor declaraţii. În practica de expertiză am întâlnit astfel de cazuri în care persoane care au participat la cercetare au făcut afirmaţii privind împrejurările în care s-a produs un eveniment. Din acest motiv expertul care interpretează urmele trebuie să fie o persoană independentă, care nu a participat activ la cercetarea la faţa locului, dar care a luat contact cu locul faptei direct sau prin intermediul imaginilor fotografice sau/și video. „Interpretarea urmelor trebuie să genereze idei originale rezultate exclusiv de examinarea urmelor în corelaţie cu locul faptei."

${ }^{5}$ L. Ionescu, D. Sandu, op. cit., p. 49.

${ }^{6}$ Ibidem, p. 50.

${ }^{7}$ I. Anghelescu, Norme deontologice ale specialistului și expertului criminalist - Tratat practic de criminalistică - vol IV, Editura Ministerului de interne, București, 1982 pag. 261.

${ }^{8}$ Gh. Pășescu, op. cit., p. 61 


\subsection{Principiul elaborării tuturor variantelor}

Crearea urmelor de obicei se produce în împrejurări unice și într-un mod unic. În cazul în care în contextul locului faptei urmele care s-ar fi putut produce în mai multe variante sau ipoteze, este necesar să fie epuizate prin analiză și interpretare toate variantele posibile, astfel încât concluziile să fie cât mai clare.

\section{Etapele cercetării la fața locului}

\subsection{Sesizarea și dispunerea efectuării cercetării la faţa locului}

Organele de cercetare penală sunt sesizate prin apel de urgenţă, plângere directă sau prin autosesizare ori sesizare din oficiu.

În urma sesizării este emisă o ordonanţă prin care se dispune cercetarea la faţa locului pentru fapta sesizată (în cazul cercetării la faţa locului efectuată în cursul urmăririi penale).

\subsubsection{Constituirea echipei de cercetare}

Cercetarea locului faptei se face conform legii (art. 192 C. pr. pen ${ }^{9}$ ). Organul de cercetare penală poate solicita constituirea unei echipe formată din specialiști din mai multe domenii, în funcţie de specificul faptei (inspector SSM, medic legist, electromecanic, specialist ISCIR, biolog etc.).

\subsection{Pregătirea cercetării la faţa locului}

\subsubsection{Asigurarea, delimitarea perimetrului și îndepărtarea curioșilor}

Se vor stabili persoanele care au sesizat evenimentul și potenţialii martori. Martorii vor fi audiaţi individual și separaţi unul de celălalt pentru a evita date subiective sau eventuale puneri de acord care ar putea deruta ancheta.

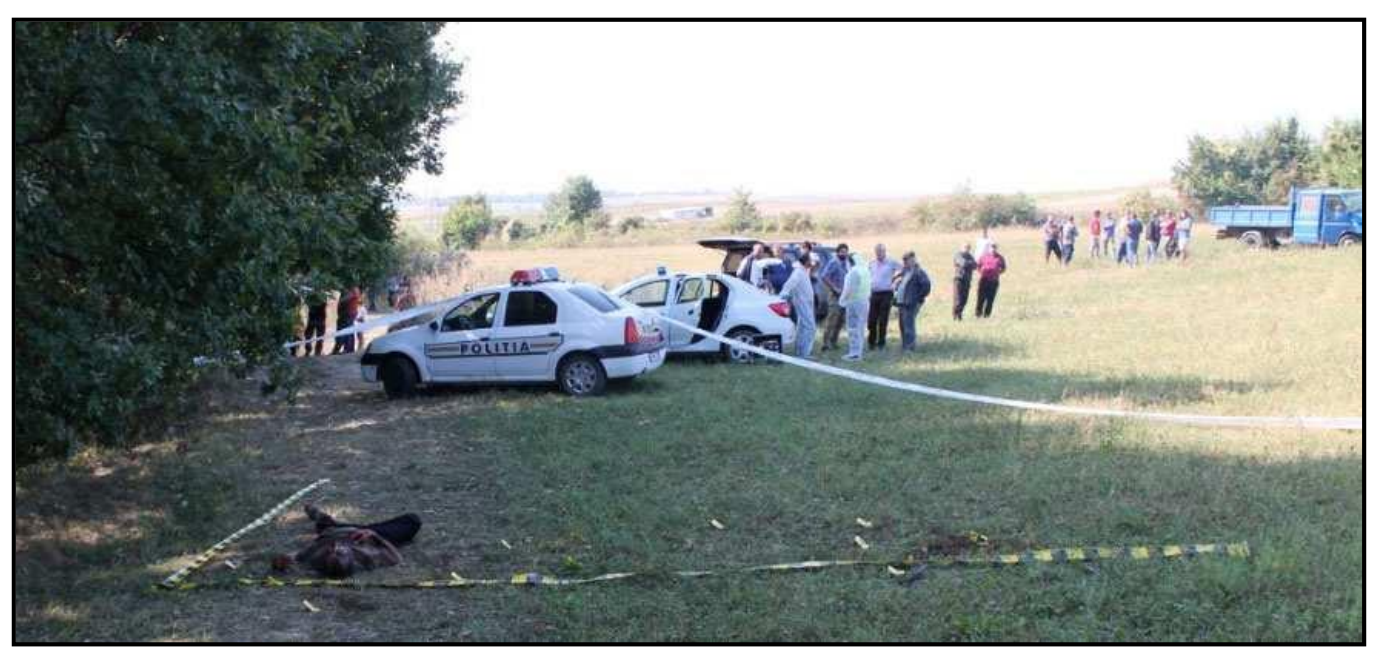

Fig. 5. Exemplu de delimitare a perimetrului locului faptei

${ }^{9}$ Legea nr. 135/2010 privind Codul de procedură penală, publicată în M.Of. nr. 486 din 15 iulie 2010, cu modificările şi completările ulterioare. 


\subsubsection{Inspecţia locului faptei de către echipe specializate în detectarea substanţelor și gazelor periculoase}

Cercetarea locului faptei trebuie să înceapă cu activitatea de analiză de către echipe specializate în stabilirea prezenţei unor substanţe periculoase sau gaze toxice ori cu caracter exploziv, atunci când este vorba de deversări de substanţe inflamabile sau periculoase ori când cercetarea se efectuează în spaţii închise.

\subsubsection{Separarea martorilor urmată de audierea lor separată}

O activitate la fel de importantă precum cercetarea la faţa locului este identificarea și separarea martorilor în vederea audierii lor separate.

\subsection{Organizarea cercetării}

\subsubsection{Cercetarea victimelor}

În cazul prezenţei unei victime care prezintă semne vitale, se va asigura acordarea de prim-ajutor și apoi se va facilita accesul echipajelor medicale de urgenţă.

Cercetarea victimei sau a grupului de victime se va realiza cu precauţie, pentru a nu vicia locul faptei prin adăugarea de urme sau mijloace materiale de probă. După ridicarea victimei și trimiterea acesteia la spital, va fi fixată poziţia acesteia prin desenarea conturului sau prin alte mijloace (panglică, bandă adezivă colorată etc.). În cazul în care din motive obiective apar urme suplimentare sau mijloace materiale de probă datorate ajutorului acordat victimei, acestea vor fi individualizate pentru a fi excluse. De asemenea, se va urmări ca mijloacele materiale de probă să nu fie mutate sau deranjate, iar în cazul în care este neapărat nevoie, se vor fixa coordonatele sau se vor desena contururile obiectelor mutate astfel încât să se poată reproduce poziţionarea lor iniţială. În cazul în care victima sau mijloacele materiale de probă au fost mutate sau nu au mai fost găsite la locul faptei la sosirea echipei de cercetare se vor cere relaţii despre poziţionarea lor iniţială martorilor sau persoanelor prezente (atunci când este posibil). În foarte multe cazuri, mai ales în cazuri de accidente de trafic, persoane curioase sau echipe de jurnaliști efectuează fotografii sau filmări în care sunt surprinse poziţiile autovehiculelor sau victimelor imediat după accident. Până la sosirea echipei de cercetare criminalistică, autovehiculele sunt mutate în vederea descarcerării victimelor sau pentru a nu bloca traficul. În astfel de situaţii trebuie culese cât mai multe imagini și informaţii, astfel încât să poată fi reprodusă situaţia în care se găseau autovehiculele imediat după accident.

\subsubsection{Analiza corpului victimei}

Imediat ce este posibil din punct de vedere medical, se va efectua o analiză a corpului victimei de către un medic legist, care va întocmi un prim certificat constatator al leziunilor însoţit de fotografii metrice prin care vor fi fixate leziunile. Raportul medico - legal este recomandat să fie însoţit de radiografii (când s-au constatat fracturi). 


\subsubsection{Fixarea poziţiei victimei}

În cazul în care s-a constatat decesul victimei la faţa locului, se va fixa poziţia acesteia prin trasarea conturului. Se recomandă efectuarea de fotografii metrice a leziunilor şi mai ales a urmelor de sânge care provin de la cadavru şi s-au scurs pe sol. În cazul în care victima este decedată, medicul legist va furniza maximum de informaţii posibile la faţa locului (felul morţii, ora decesului etc.).

\subsubsection{Ridicarea de obiecte}

Se vor ridica hainele și încălţămintea victimei și se vor conserva în plicuri separate în vederea unor analize viitoare, deoarece obiectele de vestimentaţie și încălţămintea sunt purtătoare de urme.

\subsection{Cercetarea statică a locului faptei}

3.4.1. Alegerea metodei de cercetare ${ }^{10}$

3.4.1.1. Metoda benzilor

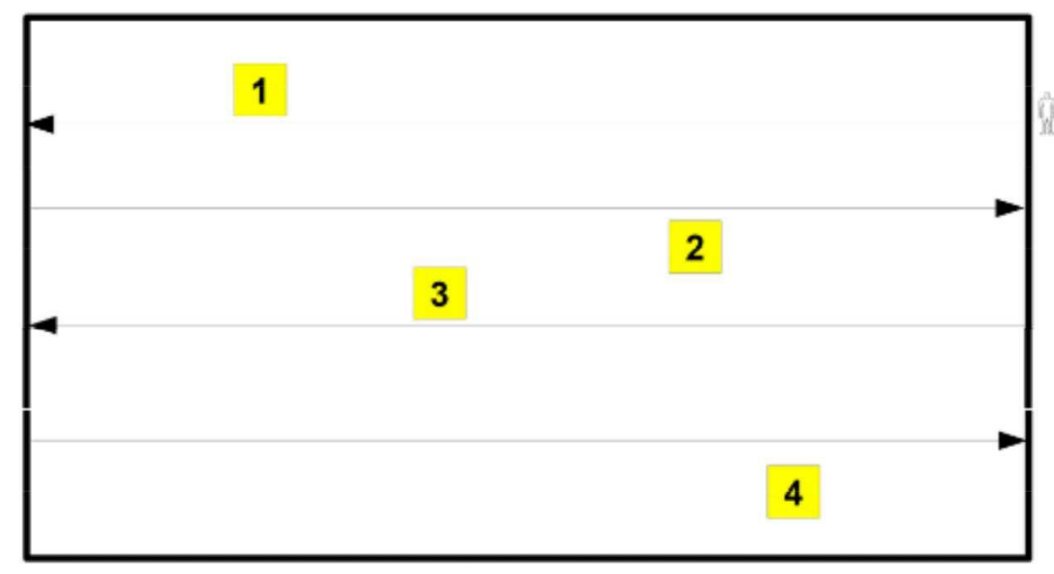

Fig. 6. Metoda benzilor

Metoda benzilor se aplică în zonele în care limitele scenei sunt bine delimitate. 1- 2 lucrători se vor deplasa paralel cu una din limite de la o extremă la alta a scenei. Lăţimea unei benzi este de maxim $1,5 \mathrm{~m}$ și se aplică în situaţia în care numărul urmelor sau al mijloacelor materiale de probă este relativ redus. $\mathrm{Pe}$ parcursul deplasării sunt identificate urmele şi mijloacele materiale de probă şi sunt marcate cu plăcuţe numerotate pentru identificare. Se recomandă la accidente rutiere, pătrunderi prin efracţie etc.

${ }^{10}$ W.G. Ekert, M.S.J. Stuart, Interpretation of bloodstain evidence at crime scene, CRC Press, 1993, pp. 94-96. 


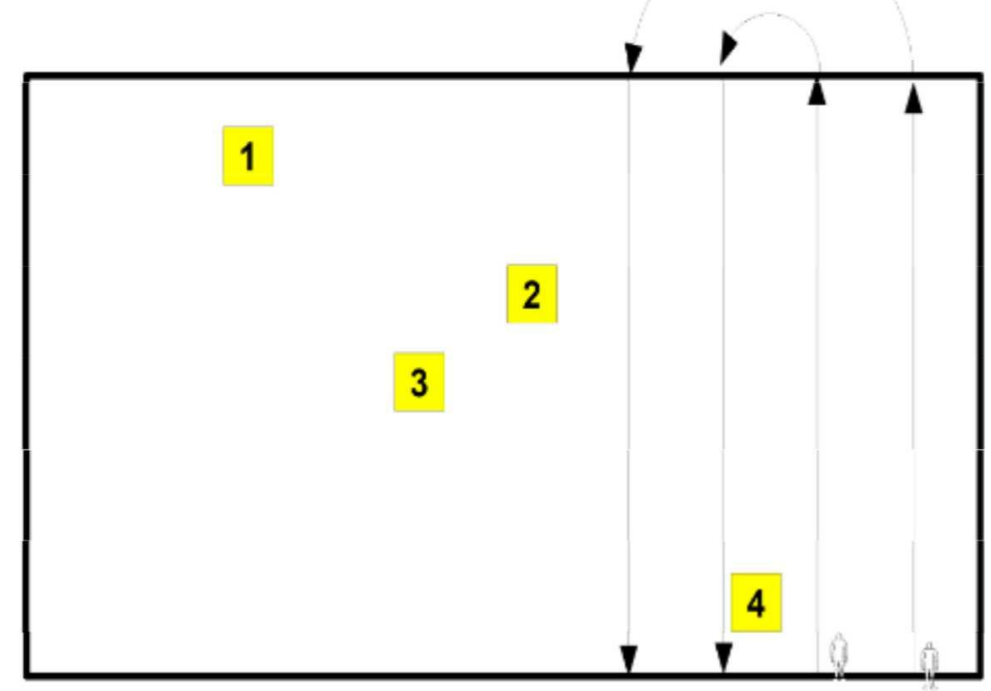

O variantă a metodei benzilor se aplică în zonele în care limitele scenei sunt bine delimitate, iar locul faptei se întinde pe distanţe mai mari de $30 \mathrm{~m}$. Doi lucrători se vor deplasa paralel cu una din laturile înguste de la o extremă la alta a scenei. Lăţimea unei benzi este de maxim $1,5 \mathrm{~m}$ și se aplică în situaţia în care numărul urmelor sau al mijloacelor materiale de probă este relativ redus. Pe parcursul deplasării sunt identificate urmele şi mijloacele materiale de probă şi sunt marcate cu plăcuţe numerotate pentru identificare.

\subsubsection{Metoda reţelei}

Este asemănătoare metodei benzilor numai că deplasarea se efectuează atât pe lungime cât şi pe lăţime. Necesită doi lucrători şi se aplică acolo unde scena crimei se întinde pe o suprafaţă mare, 50 X 30 m de exemplu.

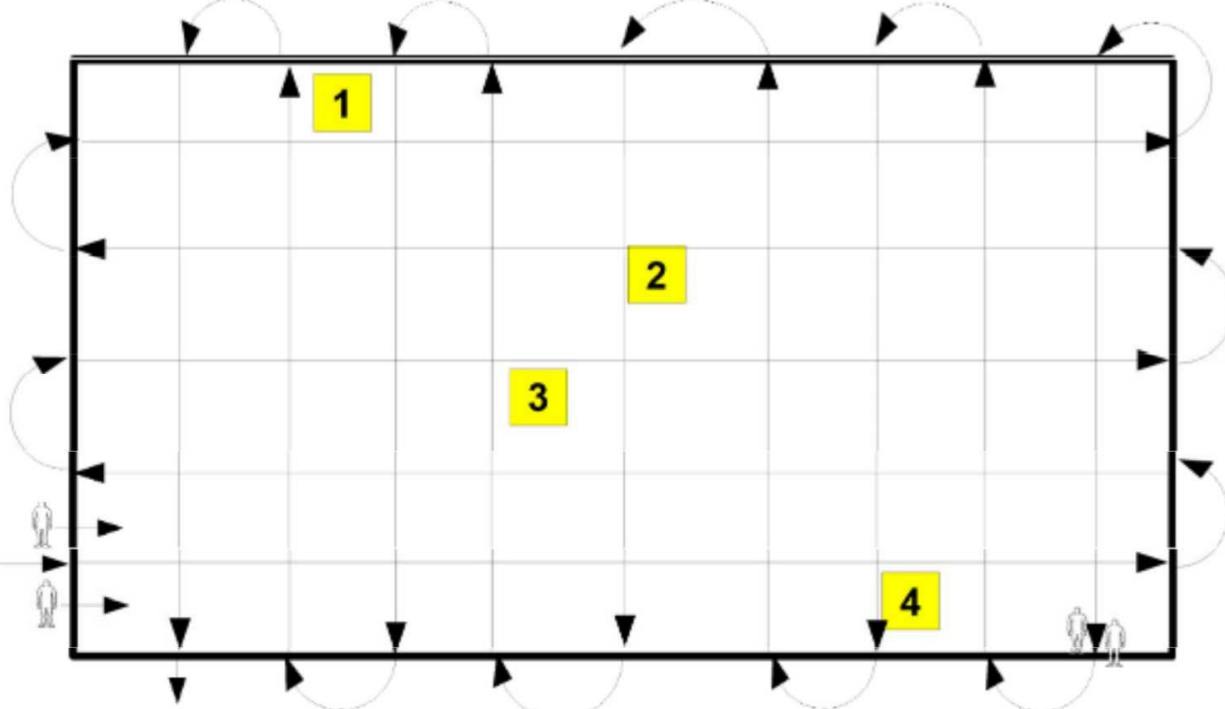

Fig. 8. Metoda rețelei 


\subsubsection{Metoda spiralei}

Cercetarea se face urmând un traseu circular, în spirală, care pornește de la zona de interes (de obicei de la cadavru, epavă, focar de incendiu, focar de explozie etc.) în sens invers acelor de ceasornic spre periferia perimetrului cercetat. Se poate aborda și invers traseul, adică de la periferie spre zona de interes şi în sensul acelor de ceasornic. Se va alege metoda cea mai la îndemână în funcţie de situaţie.

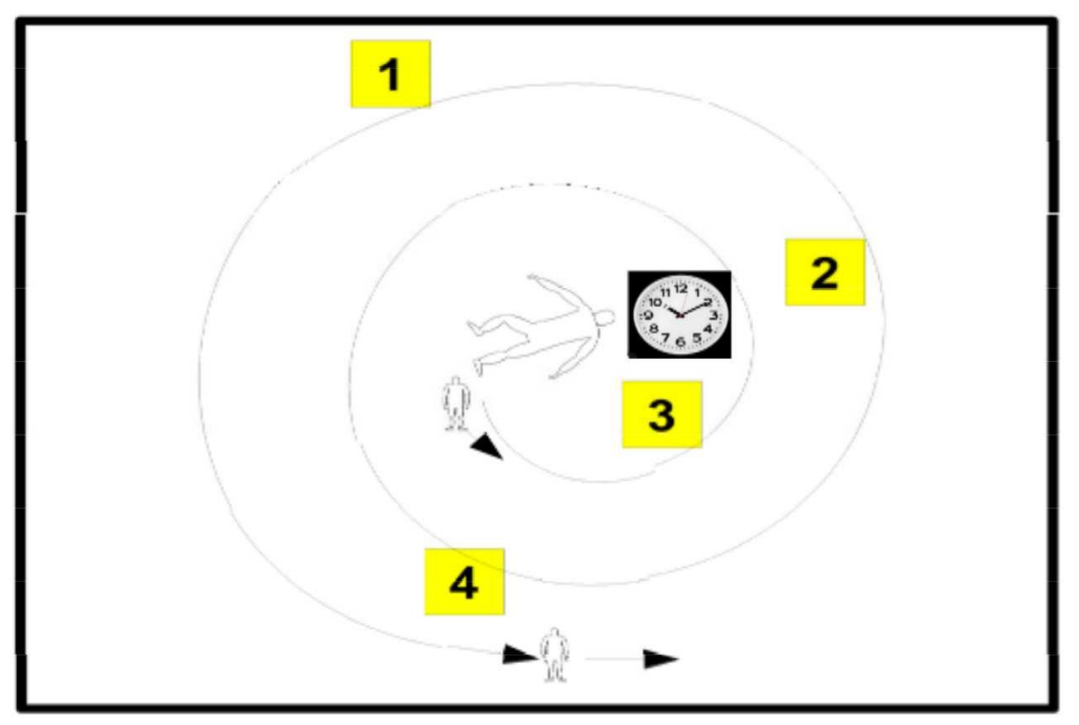

Fig. 9. Metoda spiralei

\subsubsection{Metoda roţii}

Cercetarea pornește de la locul de interes spre periferia câmpului infracţional. Se recomandă când zona de interes (cadavru sau urme de sânge, epavă etc.) se află în aer liber în zone deschise (pieţe, câmpii etc.). În această metodă sunt mobilizaţi un număr mare de lucrători și există multe urme şi mijloace materiale de probă.

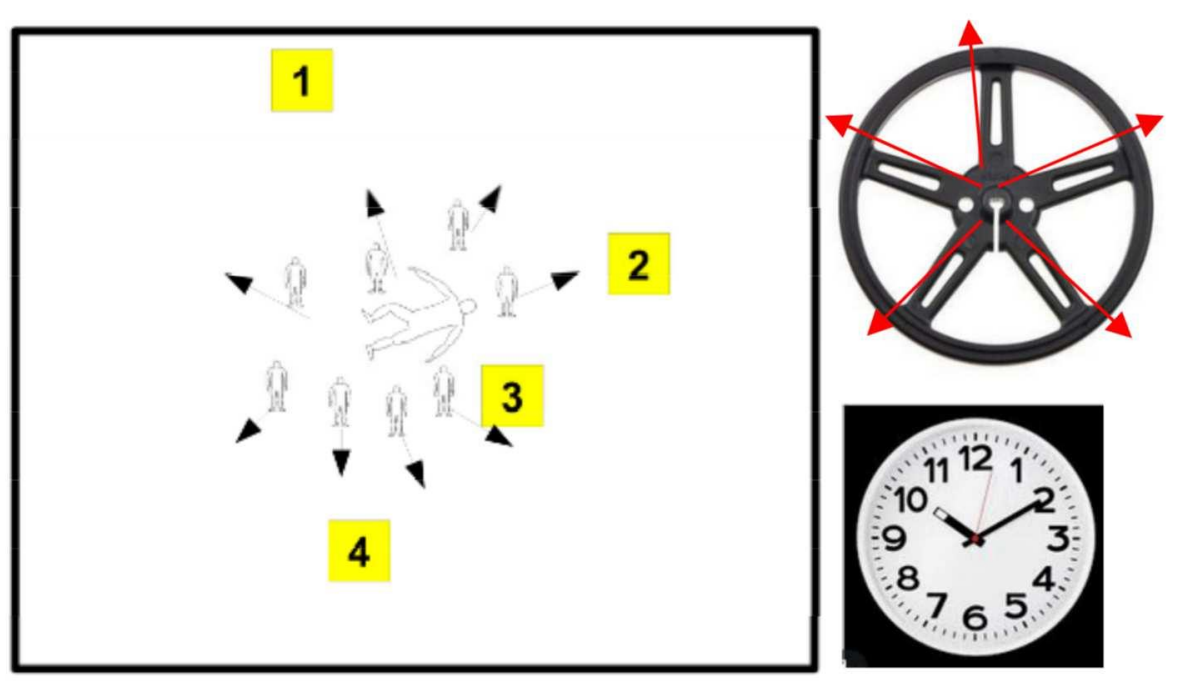

Fig. 10. Metoda roții 


\subsubsection{Metoda zonării}

În locuri bine delimitate cu suprafețe mari (hale, depozite etc.) este preferabil de ales metoda zonării.

Se împarte perimetrul în carouri apoi, dacă este necesar, se fac divizări ulterioare - împărţirea în careuri se va efectua în funcţie de cât de numeroase sunt urmele și mijloacele materiale de probă și în funcţie de cât de extinsă este scena crimei. Cercetarea se efectuează pe fiecare careu în parte, acestea fiind notate cu litere şi numere spre a fi fixate şi identificate.

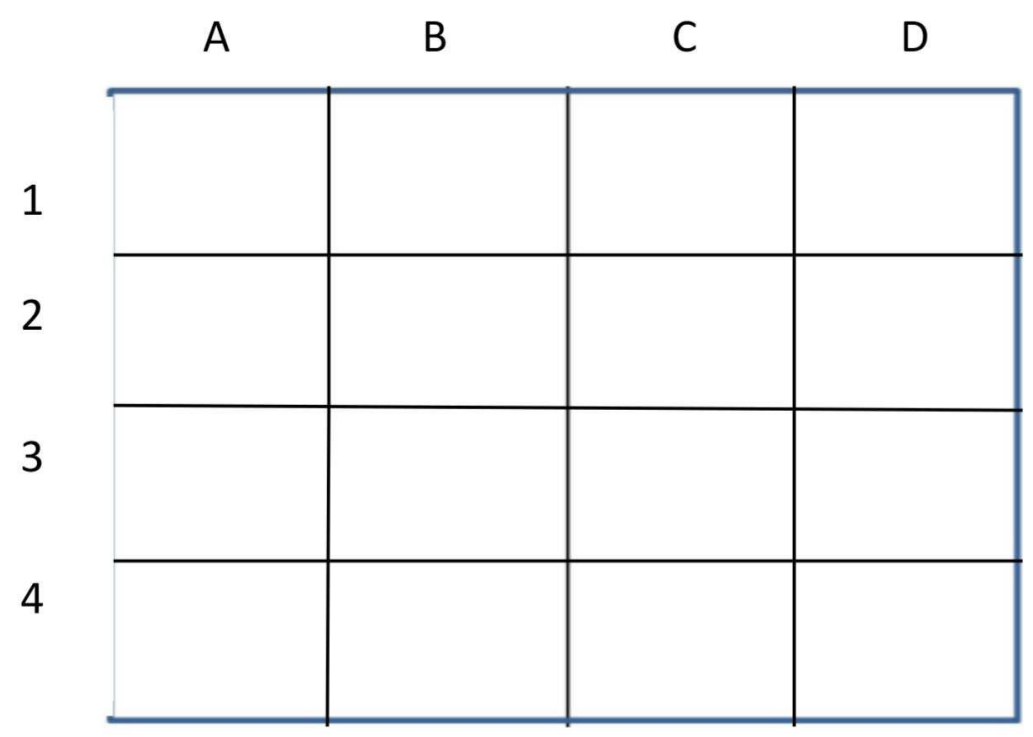

Fig. 11. Metoda zonării

Efectuarea cercetării, indiferent de metoda aleasă, trebuie să fie sistematică. Fiecare traseu va fi notat cu o literă și un număr.

După marcarea urmelor şi a mijloacelor materiale de probă se va trece la fixarea lor prin consemnarea cotelor. În vederea fixării metrice se va alege un reper fix pe cât posibil stabil în timp (bornă kilometrică, stâlp de tensiune etc.).

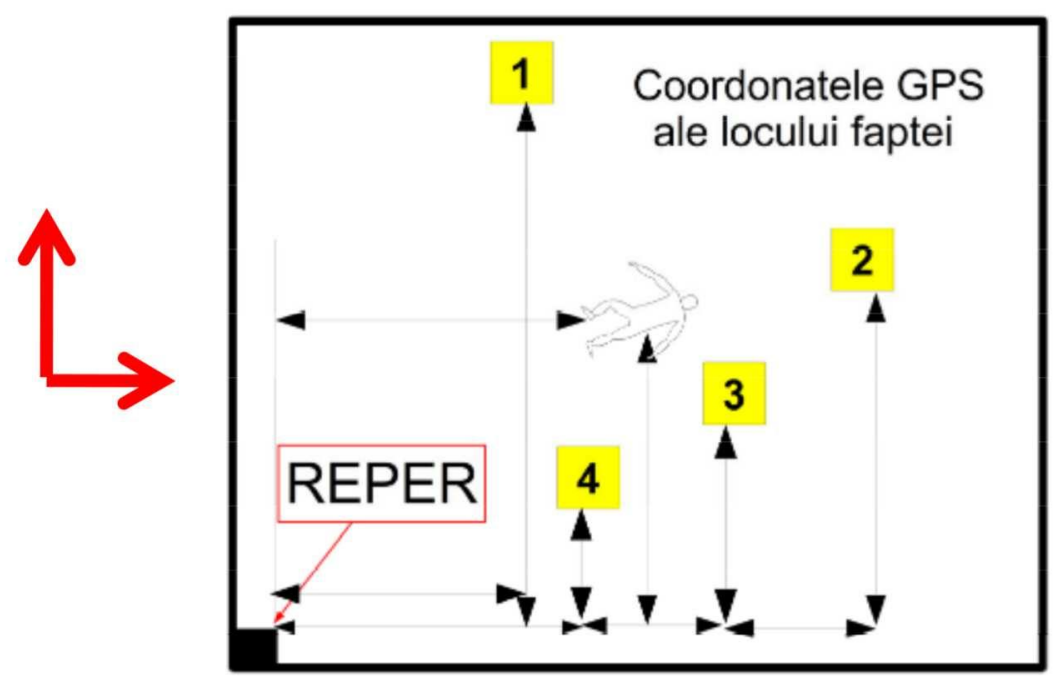

Fig. 12. Metoda zonării 


\subsection{Fixarea urmelor și a mijloacelor materiale de probă}

Pentru măsurători - pentru metodele 1,2 și 5 se ia ca reper vertical (axa ordonatei) „Y” un perete şi ca reper orizontal (axa abscisei) „X” un alt perete perpendicular pe „Y” . Fiecare urmă sau mijloc material de probă va primi două cote, una corespunzătoare axei $Y$ și una corespunzătoare axei X.

Exemplu: 1 ciob de sticlă $\mathrm{x}=3,2 \mathrm{~m}, \mathrm{y}=2,8 \mathrm{~m}$

- pentru metodele 3 și 4 se folosește metoda ceasului:

se ia ca reper axul central al acelor de ceasornic în locul de maximă importanţă - locul unde se afla victima sau locul în care se află epicentrul unei explozii.

Se stabilește poziţia ceasului cu ora 12 în dreptul unui punct de reper ales.

Fiecare urmă sau mijloc material de probă va fi notat ca poziţie și distanţă faţă de centru.

Exemplu: $\quad 1$ ciob de sticlă $15 ; 2,3$ m

Prima cifră înseamnă minutul 15 și a doua cifră distanţa faţă de centru. Se folosește doar indicaţia acului minutelor - cadranul ceasului are 60 de minute.

\subsection{Cercetarea dinamică a locului faptei}

Cercetarea dinamică a locului faptei presupune activităţi de fotografiere, filmare, relevare de urme, ridicări de mijloace materiale de probă, mulaje, ascultarea martorilor etc. Asupra acestor aspecte nu insistăm întrucât vor face obiectul unei lucrări viitoare.

\subsubsection{Filmarea și/sau fotografia de orientare}

Fotografia de orientare trebuie efectuată din cel puţin două direcţii opuse pentru a oferi o imagine de ansamblu.

\subsubsection{Fotografia de detaliu}

Fotografia de detaliu presupune fotografierea metrică de detaliu a fiecărei urme și mijloc de probă din 2-3-4 unghiuri diferite sau câte sunt necesare, pentru a surprinde cât mai multe detalii și particularităţi.

\subsubsection{Relevarea și ridicarea urmelor}

Relevarea urmelor (palmare, plantare, papilare, a urmelor de fluide corporale etc.) este o activitate pe care specialiștii o desfasşoară folosind trusa din dotare, care este echipată cu ustensile și substanţe speciale, dedicate scopului relevării a diferite categorii de urme.

Ridicarea urmelor de efracţie sau impresiunilor de pneuri, tălpi de încălţăminte etc. trebuie făcută în ordinea specifică metodei de cercetare aleasă. Urmele vor fi fotografiate și fixate metric, după care vor fi ridicate cu ajutorul materialelor speciale dedicate tipului de urmă - cauciuc sau pastă siliconică, ipsos etc. Mulajele ridicate vor fi etichetate și depozitate în ambalaje individuale. $\mathrm{Nu}$ trebuie neglijată nicio urmă, chiar dacă ni se pare irelevantă, deoarece aceasta poate conţine un detaliu pe care celelalte urme create de același obiect nu-l conţin sau 
pot furniza informaţii utile cu privire la modul ori împrejurările în care a fost comisă o infracţiune. De exemplu, se pot stabili traseele pe care s-au deplasat autorii sau autorul pe baza reconstituirii „cărării de pași”.

\section{4. Încheierea cercetării la faţa locului}

Cercetarea la faţa locului se va considera terminată după ce va fi încheiat un proces-verbal în care vor fi menţionate amănunţit toate activităţile efectuate, măsurătorile etc.

În procesul-verbal se vor menţiona actul prin care s-a dispus cercetarea, echipa care a efectuat cercetarea și locul unde s-a înregistrat evenimentul, data efectuării cercetării la faţa locului, condiţiile meteo și de ambient. Data efectuării cercetării poate fi diferită de cea a încheierii procesului verbal, acesta fiind întocmit la o dată ulterioară după ce s-au inventariat toate datele și s-au întocmit, eventual, ciornele sau notiţele din agenda de lucru. Procesul-verbal va fi citit și semnat de luare la cunoștinţă de către cei care au făcut parte din echipa de cercetare și de către martorii care au asistat la efectuarea cercetării. Dacă există observaţii cu privire la activităţile desfășurate, acestea vor fi menţionate în procesul verbal.

Procesul-verbal de cercetare la faţa locului va fi însoţit de schiţa sau schiţele locului faptei și de planșa sau planșele foto. Este recomandabil ca fotografiile operative judiciare şi filmările să fie stocate în format electronic pe suport optic sau memorie flash și să însoţească procesul verbal la constituirea dosarului cauzei.

\section{Referinţe}

Anghelescu, I. Norme deontologice ale specialistului și expertului criminalist - Tratat practic de criminalistică - vol IV, Editura Ministerului de Interne, București 1982

Ekert, W.G., Stuart, M.S.J., Interpretation of bloodstain evidence at crime scene, CRC Press, 1993

Ionescu, L. Sandu, D., Identificarea criminalistică, Editura Știinţifică București, 1990

Mircea I., Valoarea criminalistică a unor urme de la faţa locului, Editura V. Goldiș, Arad, 1996.

Pășescu, Gh., Interpretarea criminalistică a urmelor la locul faptei, Editura Naţional, 2000 